\title{
Recent Financial Crisis and International Politics: An Analysis of Efforts to Save US Economy at the Cost of Developing Economies
}

\section{Yadav DK*}

Assistant Professor, Department of Economics, Babasaheb Bhimrao Ambedkar University, Lucknow, India

\begin{abstract}
Recent financial crisis which has pushed almost whole world under recession, has also affected the developing economies in many ways. Since its starting, academicians were talking about its impact on world economies in different ways. Some of them were looking the crisis as an opportunity particularly for developing countries. India and China are emerging as two most prominent face of developing economies, and it may have been an opportunity for them to strengthen their global order among the economies of world. Subprime crisis of US financial system has badly affected the US economy and weaken its position. It has been said that balance of payment position of U.S. economy is in very bad shape, and if china wish it can destabilize the U.S. economy. It has also been said that U.S. currency (\$) may not enjoy the position (as international currency) and credit worthiness which it has earlier. It could have an opportunity to make a multi-polar world. But happenings of the post recession period shows that nothing much have changed, and U.S. economy almost continued its status as it was in pre crisis period.

Present paper will be normative analysis to understand the politics and economics of world originations and institutions those have worked hard and fast to save the U.S. economy. It will also be attempted to understand the factors those have pushed the economies like India in double dip recession. Is there any role of international politics and world organizations in this pathetic situation, when it is being claimed that it is because of policy paralysis?
\end{abstract}

Keywords: Financial crisis; Politics; Recession; Indian economy

\section{Introduction}

Since starting of US financial crisis and its impact on US economy as well as on the rest of world, academicians were comparing it with great depression of 1929. Its impact was so severe that within very short period of time financial institutions those have experience of centuries and very large asset and capital base collapse like playing cards (viz. Lehman brothers and others). It was basically crisis of derivative securities, those are considered as instrument of risk mitigation and management, but became source of risk because of weak primary securities generated through subprime lending. Almost whole financial system of US economy was collapsed due to the crisis. Financial system of an economy is being considered as heart of economy, which efficient functioning is must for efficient functioning of economy. It was reflected during US financial crisis, when size of GDP and employment reduced sharply in USA. It was also supposed that domination of US currency (\$) as international currency will also be weaken, because the value and demand of a currency is very much dependent on fundamentals of economy which was very weak in case of US economy. Its impact was not limited to only USA, but has also affected severely to countries those have trade relation with USA and pushed almost whole world under recession. Developed countries were affected more severely than developing and underdeveloped countries [1]. It was once argued that financial crisis may provide an opportunity to convert world from unipolar to multipolar, particularly it may be an opportunity for developing countries like India and china to strengthen their position in global orders of economies. People were looking at it as first episode of $21^{\text {st }}$ century of emergence of Asian countries.

But the experiences of post crisis period shows that nothing much have changed, and US has continued its dominance as super economic power and its currency was almost intact to the financial crisis. Not only this, when US economy is showing the sign of recovery and positive growth rate; developing countries like India are facing the problem of double dip recession. In this context the relevant question which arise is how come the economic position of US economy remain intact even after facing very severe financial crisis and why weakened fundamentals of US economy has not affected to its currency (\$)? What was the role of world organisations and institutions in this context? How the international politics has helped to save the US economy from collapsing? And lastly is there any role of international politics and world organisations in the double dip recession of Indian economy?

Rest of paper is organised in to four sections. Second section analyse the impact of subprime crisis on financial system of developed and developing countries [2]. Third section examines the impact of financial crisis on economic activities of developed and developing countries in pre and post crisis period. Normative analysis to understand the role of international politics and world organisations to save the US economy and its currency is included in to fourth section. It also includes double dip recession problem of Indian economy. Fifth section presents the conclusion of the paper.

\section{Impact of Subprime Crisis on Financial System of Developed and Developing Countries}

Four indicators, viz. Grass Non-performing assets (GNPA), Capital to Risk weighted Asset Ratio (CRAR), and Return on Asset (ROA) have been chosen to assess the impact of subprime crisis on financial system of developed and developing countries.

*Corresponding author: Dr. Yadav DK, Assistant Professor, Department of Economics, Babasaheb Bhimrao Ambedkar University, Lucknow, India, Tel: 08400754176; E-mail: dev1985icfai@gmail.com

Received July 24, 2015; Accepted September 29, 2015; Published October 05 2015

Citation: Yadav DK (2015) Recent Financial Crisis and International Politics: An Analysis of Efforts to Save US Economy at the Cost of Developing Economies. J Glob Econ 3: 155. doi:10.4172/2375-4389.1000155

Copyright: (c) 2015 Yadav DK. This is an open-access article distributed under the terms of the Creative Commons Attribution License, which permits unrestricted use, distribution, and reproduction in any medium, provided the original author and source are credited. 


\section{Non-performing Assets (NPA)}

High NPA raise the cost of bank operations and thereby the spread and efforts need to be made to bring these down. Indian banking system has made a significant stride in this direction to bring it down. It has decreased from 14.4\% in 1998 to 8.8 in 2003 and further halved it to its minimum level of 2.3 percent in 2010. If we compare the performance of Indian banks to banks of other developed countries and developing countries banking system in terms of NPA, we find year of 2007 as divider year. Before 2007, most of the developed countries were in better position than developing countries in general and India in particular. Some South American developing countries were exception, those performance were as per and some cases better than developed countries. However, in period of post 2007 (when problem of recession started) situation has just reversed. After 2007, performance of developing country's banking system improved while performance of developed countries worsened because of default in subprime lending and recession. NPA of US banking system increased sharply from 0.8 percent in 2006 to 5.5 percent in 2010. Similar situation was in other developed countries, except Japan which is an Asian country. How the NPA of Japanese banking system did not increase is question of great relevance for researcher, given the very basic nature of Japanese economy which is export led?

From the Figure 1, it is very much clear that GNPA of developed countries has declining trend up to 2005, it started increasing thereafter and it continue up to 2008 (Period of financial crisis), and then again started declining. But still GNPA of developed countries banking system is significantly high than their GNPA in pre-recession period.

In case of developing countries, most of them either improved their performance or sustained their low level of NPA except one two countries like Pakistan. NPA of Pakistan's banking system has increased sharply from 6.9 percent in 2006 to 13.1 percent in 2010. In post-recession period, Indian banks have registered huge improvement in their NPA account. Now it is one of the most competitive banking systems of the world in terms of NPA. Indian bank's NPA remain intact

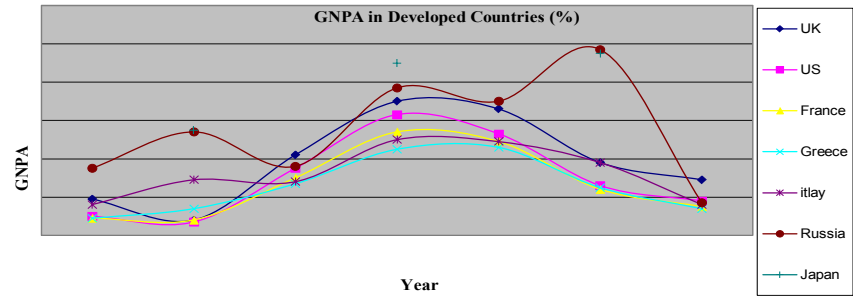

Figure 1: GNPA of developed countries has declining trend up to 2005 , it started increasing thereafter and it continue up to 2008 (Period of financial crisis), and then again started declining.

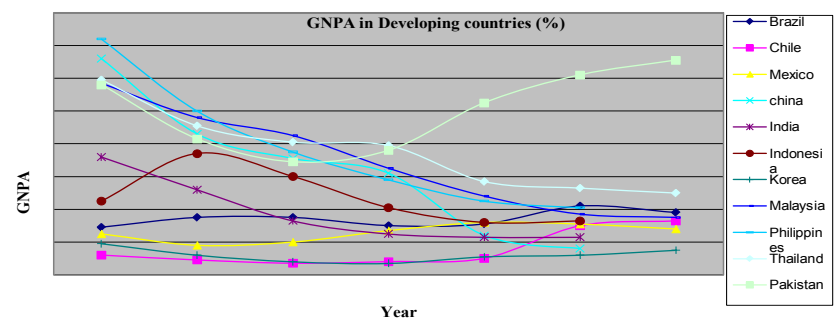

Figure 2: Clearly indicate the declining trend in GNPA of developing countries and financial crisis did not affect the performance of banking system of these countries.

\begin{tabular}{|l|c|c|c|c|c|c|}
\hline Country & $\mathbf{2 0 0 0}$ & $\mathbf{2 0 0 1}$ & $\mathbf{2 0 0 2}$ & $\mathbf{2 0 0 3}$ & $\mathbf{2 0 0 4}$ & $\mathbf{2 0 0 5}$ \\
\hline India & 0.7 & 0.6 & 0.8 & 0.9 & 1.1 & 1 \\
\hline Indonesia & -9.1 & -4.4 & - & 0.1 & 0.8 & 1.8 \\
\hline Korea & -0.9 & -3.3 & -1.3 & -0.6 & 0.8 & $0-8$ \\
\hline Malaysia & - & - & 1.1 & 1.1 & 0.8 & - \\
\hline Pakistan & -1.2 & 0.5 & -0.2 & -0.2 & -0.5 & - \\
\hline Philippines & 1.7 & 0.8 & 0.4 & 0.4 & 0.4 & 0.7 \\
\hline Thailand & -0.8 & -5.1 & -5.4 & -1.6 & -0.2 & 0.7 \\
\hline USA & 1.3 & 1.1 & 1.3 & 1.2 & 1.1 & 1.4 \\
\hline Japan & 0.0 & -0.6 & -0.5 & 0.2 & 0.0 & -0.4 \\
\hline Canada & 0.7 & 0.5 & 0.7 & 0.7 & 0.6 & 0.5 \\
\hline UK & 0.9 & 0.8 & 1.0 & 0.9 & 0.6 & 0.7 \\
\hline
\end{tabular}

Source: Ernst and Young

Table 1: Return on Assets of different countries banking system.

under recession and continue to decline in post-recession period [3-5].

Figure 2 clearly indicate the declining trend in GNPA of developing countries and financial crisis did not affect the performance of banking system of these countries; rather their performance seems to improve and converge towards lower side in period of financial crisis and thereafter.

\section{Return on Assets (ROA)}

Indian banks are way ahead of their global counterparts when it comes to return on assets, a parameter which denotes the efficiency. Except for bank of America and citi group, not too many of global giants can match Indian banks in terms of ROA. In year of 2004, bank of America's ROA was 1.91 percent, while that of citi group's was 1.63 percent. Andhra bank's ROA was not far behind at 1.59 percent. Among other Indian commercial banks, Oriental bank of commerce's (OBC) ROA was 1.41 percent, HDFC bank's 1.29 percent ICICI and Allahabad bank's 1.20 percent, Punjab National Banks 1.12 percent and Canara Banks 1.01 percent. Last year SBI'S ROA was 0.94 percent. Among the top four Chinese banks only china construction bank had an ROA of 1.29 percent. The other three bank's ROA varied between 0.5 to 0.81 . Among the top 10 global giants, JP Morgan chase, credit agricol, Mitsubishi Tokyo, Mizo financial and BNP Paribus had an ROA of less than $1 \%$ (Table 1).

Indian banking system has shown consistent performance in terms of profitability even under period of recession when most of the top banks of developed countries have registered huge loss in their account and their respective governments have to come forward to save them from collapsing. Return on Assets (ROA) of Indian scheduled banks was 1.05 per cent in 2006, increased to 1.13 per cent in 2008 and then marginally declined to 1.10 per cent in 2010 [6]. If we see the graph, total earning is showing clear increasing trend in absolute terms; it became more than double in very short span of four years. However, total expenses is also increasing in same way and mitigating the effect of significant increase in total earning on profitability (ROA) of banks. Controlling the expenses, particularly the operating expenses, will be the biggest challenge for Indian banks in future. Use of modern technology can play critical role in this direction.

\section{Capital to Risk Weighted Asset Ratio (CRAR)}

Capital adequacy is an indicator of the financial health of the banking system. It is measured by the capital to risk weighed asset ratio (CRAR), defined as the ratio of bank's capital to its total risk weighted assets. Financial regulators generally impose a capital adequacy norm 
on their banking and financial systems in order to provide for a buffer to absorb unforeseen losses due to risky investment. A well adhered to capital adequacy regime does play an important role in minimizing the cascading effects of banking and financial sector crises [7].

Role of CRAR in world baking system become suddenly critical because of increasing rate of default; initially in US banking system due to subprime lending and later on in other countries because of their off balance sheet exposure; which was in mortgage backed securities. If we compare the year of 2006 to 2008, we find that CRAR ratio of most of the developed countries has decelerated, it happened because of increasing risk component in assets of developed countries banking system. However, later on in 2009 value of ratio has increased in almost all the countries. Huge compensatory packages given by their respective governments to save them from melting down have played significant role in improving their CRAR ratio.

Figure 3 shows that CRAR ratio of almost all the included developed countries banking system has declined suddenly in year of 2007; except Russia. It points out the increased component of risk in portfolio of banking assets of developed countries. However the declining trend has reversed after 2008, because of high compensation provided by governments to banks.

In developing countries CRAR ratio remain intact because of their better position in asset quality and low level of NPA $[8,9]$. Indian banking system has registered consistent growth in CRAR ratio. According to RBI, CRAR ratio of Indian schedule banks was 3.0 percent in 2007 (crisis year), which increased to 14.54 percent in 2009 and then marginally decreased to 14.17 percent in 2010. It shows that Indian Banks are in very strong position in comparison to their foreign counterparts in terms of CRAR ratio.

From Figure 4, it is obvious that financial crisis has not affected the assets quality of developing countries; except one two countries like Argentina and Philippines. Most of the countries have shown consistent performance in terms of CRAR ratio and remain almost intact to financial crisis.

\section{Impact of Financial Crisis on Economic Activities of Developed and Developing Countries}

Financial crisis has affected much adversely to economic activities of developed countries than the developing countries. It seems natural as origin of problem was in USA and other developed countries such as UK have much more exposure in financial market of USA than

Movement in CRAR in Developed countries (\%)

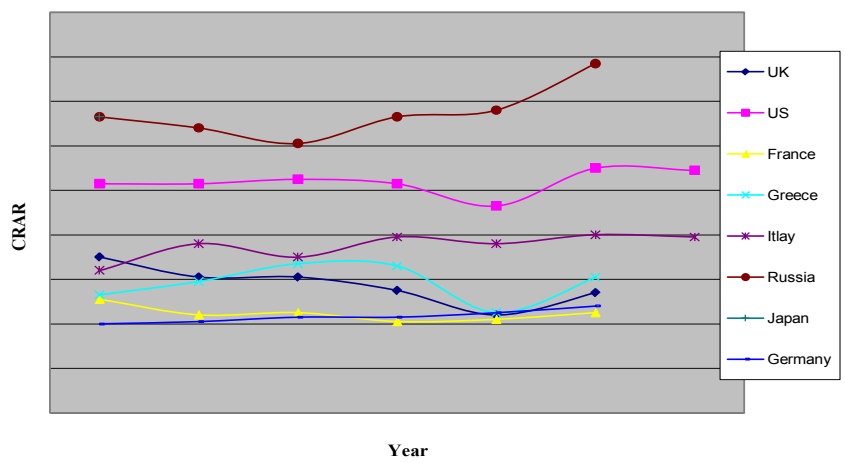

Figure 3: CRAR ratio of almost all the included developed countries banking system has declined suddenly in year of 2007; except Russia.

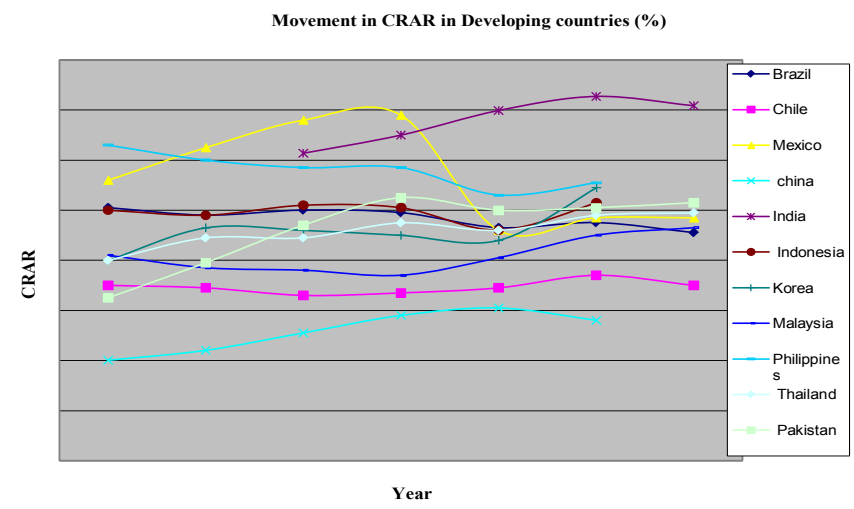

Figure 4: Financial crisis has not affected the assets quality of developing countries; except one two countries like Argentina and Philippines.

developing countries [10]. From Table 2 of growth rate it is very much clear that growth rate of developed countries declined from positive growth rate to significantly negative. Growth rate of US economy was 2.6 per cent in 2006 , which declined to -3.1 in 2009 . It has also affected to growth rate of developing countries but comparatively in small intensity. Growth rate of India and China declined from 9.2 per cent to 4.0 per cent and 12.7 per cent to 9.6 per cent respectively in the same period. Sharp decline in growth of developed countries may be explained by their sharp decline in capital formation. Capital formation in USA and UK has declined from 20.15 per cent and 17.45 per cent in 2006 to 14.09 and 14.14 per cent in 2009, respectively. However, in the same corresponding period in case of developing countries capital formation was consistent and registered a meagre growth (given in Table 3 of capital formation). Fact is also reflecting in terms of unemployed labour force in total labour force. While the unemployment in developed countries has increased sharply in crisis period, it remains intact in case of developing countries. In USA and UK unemployment has increased from 4.6 per cent to 9.1 per cent and 5.4 per cent to 7.7 per cent, respectively in crisis period. Looking these figures it can be said that financial crisis has badly affected to the developed countries and serious action on their part. But whether financial crisis was equally serious for developing countries is question of serious research? Looking the figures of capital formation and unemployment in these countries during crisis period, it can be said that it was not as serious as in case of developed countries. But it was propagated as very serious problem not only for developed countries but for developing countries as well. Different world organisation and institutions have played very critical role in this direction. They have convinced to developing countries to implement expansionary fiscal policy at large scale and they were success in their motive. Developing countries such as India has announced special packages in form of MNREGA, sixth pay commission, loan waiving for farmers, tax holidays and fiscal support to corporate sector. But experience of post crisis period shows that these kind of special packages were more beneficial for developed countries than their own (developing countries), rather it has harmed to their economic interest. Figures of post crisis period shows that while developed countries recovered very fast in the post crisis period; developing countries like India are facing the problem of double dip recession. Growth rate of USA recovered from -3.10 per cent in 2009 to 2.21 per cent in 2012, but growth rate of India has slipped from 8.4 per cent to 3.2 per cent in the same corresponding period of time. People are arguing that it is because of policy paralysis, but it is not true. Actually it is because of unwarranted expansionary fiscal 
Citation: Yadav DK (2015) Recent Financial Crisis and International Politics: An Analysis of Efforts to Save US Economy at the Cost of Developing Economies. J Glob Econ 3: 155. doi:10.4172/2375-4389.1000155

Page 4 of 6

\begin{tabular}{|l|c|c|c|c|c|c|}
\hline Country & $\mathbf{2 0 0 6}$ & $\mathbf{2 0 0 7}$ & $\mathbf{2 0 0 8}$ & $\mathbf{2 0 0 9}$ & $\mathbf{2 0 1 0}$ & $\mathbf{2 0 1 1}$ \\
\hline India & 9.263965 & 9.80136 & 3.890957 & 8.479784 & 10.54639 & 6.330518 \\
\hline China & 12.7 & 14.2 & 9.6 & 9.2 & \multicolumn{2}{|c|}{3.236943} \\
\hline Brajil & 3.955415 & 6.095455 & 5.169299 & -0.32825 & 7.533615 & 2.732509 \\
\hline USA & 2.659121 & 1.907213 & -0.35909 & -3.10906 & 2.379827 & 1.800339 \\
\hline England & 2.600427 & 3.632672 & -0.96788 & -3.97442 & 1.79932 & 0.992301 \\
\hline Japan & 1.692904 & 2.192186 & -1.04164 & -5.52698 & 4.652112 & -0.57032 \\
\hline
\end{tabular}

Source: World Bank, 2013

Table 2: Growth rate.

\begin{tabular}{|l|c|c|c|c|c|c|}
\hline Country & $\mathbf{2 0 0 6}$ & $\mathbf{2 0 0 7}$ & $\mathbf{2 0 0 8}$ & $\mathbf{2 0 0 9}$ & $\mathbf{2 0 1 0}$ & $\mathbf{2 0 1 1}$ \\
\hline India & 35.87169 & 38.03419 & 35.5254 & 36.29696 & 36.97623 & 35.44782 \\
\hline China & 42.97175 & 41.73773 & 44.04627 & 48.24343 & 48.06255 & 48.31465 \\
\hline Brajil & 16.75576 & 18.32763 & 20.69445 & 17.83803 & 20.23862 & 19.72626 \\
\hline USA & 20.15021 & 19.17231 & 17.53673 & 14.09597 & 14.84112 & 14.91465 \\
\hline England & 17.45398 & 18.30703 & 17.11366 & 14.1461 & 15.1028 & 14.86389 \\
\hline Japan & 22.68063 & 22.88358 & 22.97685 & 19.66527 & 19.82349 & 19.95633 \\
\hline
\end{tabular}

Source: World Bank, 2013

Table 3: Capital formation.

\begin{tabular}{|l|c|c|c|c|c|c|}
\hline Country & $\mathbf{2 0 0 6}$ & $\mathbf{2 0 0 7}$ & $\mathbf{2 0 0 8}$ & $\mathbf{2 0 0 9}$ & $\mathbf{2 0 1 0}$ & $\mathbf{2 0 1 1}$ \\
\hline India & 6.145522 & 6.369997 & 8.351816 & 10.87739 & 11.9923 & 8.857845 \\
\hline China & 1.463189 & 4.750297 & 5.864384 & -0.70295 & 3.314546 & 5.41083 \\
\hline Brajil & 4.183681 & 3.637028 & 5.663099 & 4.886408 & 5.038317 & 6.636199 \\
\hline USA & 3.225944 & 2.852672 & 3.8391 & -0.35555 & 1.640043 & 3.156842 \\
\hline England & 2.333528 & 2.321036 & 3.613499 & 2.166231 & 3.285714 & 4.48424 \\
\hline Japan & 0.240664 & 0.057952 & 1.37349 & -1.34672 & -0.71978 & -0.28333 \\
\hline
\end{tabular}

Source: World Bank, 2013

Table 4: Inflation.

policy which has created artificial demand bubble in to the economy [11]. Excess demand has contributed to raise in general price level and ultimately to consistent double digit inflation. Table 3 shows that general price level in India, measured through consumer price index, has raised consistently from comfortable level of close to 6 per cent in 2006 to close to 12 per cent in 2010 , and nearly by 10 per cent even thereafter. Consistent high rate of inflation has generated uncertainties and speculations in to the system which has affected to other macro variable such as institutional saving, investment and through that to the growth rate. Inflation has also badly affected to exchange rate of Indian rupee by adversely affecting to balance of trade and fundamental of economy. Depreciation of Indian rupee has dug another set of blow for economy by weakening its position at international level and among global investors. On the basis of these available evidences it can be claimed that very high and consistent expansionary fiscal policy was not in interest of developing countries rather in interest of developed countries. It seems that developing countries is being used by developed countries at their own cost.

Another important source which has helped to save the US economy from the financial crisis was the value of its currency (\$) in foreign exchange market, which was almost intact and consistently maintained at high level. Exchange rate of US \$ shows that its value in terms of SDR hovered around .65 (per unit \$) with very little variation of .018. Theoretically it is understood that value of currency of any particular country is explained by robustness of fundamental variables of that country. If fundamentals are strong, currency is supposed to appreciate and vice versa. But this is not applicable in case of US \$. Fundamental variables of US economy were badly affected during financial crisis but it has not affected to value of US \$. It seems that again world organisations and international politics have played critical role in favour of US \$, by maintaining their artificial confidence in US \$ as international currency. It could have been an opportunity to promote SDR as international currency in place of US \$, but world organisations such as IMF has not taken interest in this direction because of international politics. Continue acceptance of US $\$$ as international currency has helped US economy to shift its problem to other countries and to use their advantages in its interest. In this endeavour China was great help for USA, as it had very high reserve of US \$ even then maintained its confidence in it (Tables 4-7).

\section{Normative Analysis to Understand the Role of Interna- tional Politics and World Organisations}

Looking the severity of financial crisis which was once compared with great recession of 1929 was expected to bring significant change in global order of world economies. It was expected that developing economies, particularly Asian economies may strengthen their position in comparison to developed countries. It has also been said that it may be an opportunity to convert the world from unipolar to multipolar. But experience of the post crisis period shows that nothing much have changed and USA continued to dominate to world economies and its currency (\$) also continued to enjoy the status of international currency. In this concern relevant question arises when US financial system totally collapsed due to the subprime crisis how come the value of its currency has not affected and US economy has re-emerged as super power within very short span of time period? Available evidence indicates that international politics and world organisations have 
Citation: Yadav DK (2015) Recent Financial Crisis and International Politics: An Analysis of Efforts to Save US Economy at the Cost of Developing Economies. J Glob Econ 3: 155. doi:10.4172/2375-4389.1000155

Page 5 of 6

\begin{tabular}{|c|c|c|c|c|c|c|}
\hline Country & 2006 & 2007 & 2008 & 2009 & 2010 & 2011 \\
\hline India & 4.4 & & & & 3.5 & \\
\hline China & 4.1 & 4 & & & 4.1 & 4.1 \\
\hline Brajil & 8.4 & 8.1 & 7.1 & 8.3 & & \\
\hline USA & 4.6 & 4.6 & 5.8 & 9.3 & 9.6 & 8.9 \\
\hline England & 5.4 & 5.3 & 5.3 & 7.7 & 7.8 & 7.8 \\
\hline Japan & 4.1 & 3.9 & 4 & 5 & 5 & 4.5 \\
\hline
\end{tabular}

Source: World Bank, 2013

Table 5: Unemployment.

\begin{tabular}{|c|c|c|c|c|c|c|c|}
\hline Country & 2006 & 2007 & 2008 & 2009 & 2010 & 2011 & 2012 \\
\hline India & $-9.3 E+09$ & $-8.1 E+09$ & $-3.1 \mathrm{E}+10$ & $-2.6 \mathrm{E}+10$ & $-5.2 E+10$ & $-6 \mathrm{E}+10$ & \\
\hline China & $2.32 \mathrm{E}+11$ & $3.53 \mathrm{E}+11$ & $4.21 \mathrm{E}+11$ & $2.43 E+11$ & $2.38 \mathrm{E}+11$ & $1.36 \mathrm{E}+11$ & $1.93 E+11$ \\
\hline Brajil & $1.36 \mathrm{E}+10$ & $1.55 \mathrm{E}+09$ & $-2.8 E+10$ & $-2.4 \mathrm{E}+10$ & $-4.7 E+10$ & $-5.2 E+10$ & $-5.4 \mathrm{E}+10$ \\
\hline USA & $-8 E+11$ & $-7.1 \mathrm{E}+11$ & $-6.8 E+11$ & $-3.8 E+11$ & $-4.5 E+11$ & $-4.6 E+11$ & $-4.4 E+11$ \\
\hline England & $-8.2 E+10$ & $-7.1 \mathrm{E}+10$ & $-4.1 \mathrm{E}+10$ & $-3.7 E+10$ & $-7.5 E+10$ & $-3.3 E+10$ & $-9.4 E+10$ \\
\hline Japan & $1.71 \mathrm{E}+11$ & $2.12 \mathrm{E}+11$ & $1.59 \mathrm{E}+11$ & $1.47 \mathrm{E}+11$ & $2.04 \mathrm{E}+11$ & $1.19 \mathrm{E}+11$ & $6.09 E+10$ \\
\hline
\end{tabular}

Source: World Bank, 2013

Table 6: Balance of Payment.

\begin{tabular}{|c|c|}
\hline Year & ER \\
\hline 2006 & 0.679 \\
\hline 2007 & 0.653 \\
\hline 2008 & 0.632 \\
\hline 2009 & 0.649 \\
\hline 2010 & 0.655 \\
\hline 2011 & 0.633 \\
\hline 2012 & 0.652 \\
\hline 2013 & 0.658 \\
\hline Mean & 0.651 \\
\hline S.D & 0.018 \\
\hline
\end{tabular}

Source: World Bank, 2013

Table 7: Exchange Rate (SDR per unit \$).

played very key role to save the US economy from the subprime crisis. It has been propagated that if US economy will collapse it will be danger for world economy in general and developing economies in particular. On this basis it has been argued to come each and every economies of world in rescue of US economy. Threat has been created that it will be more dangerous for developing economies because all these economies are directly indirectly very much dependent on US economy [12]. These kinds of propagations were supported by different world organisation as well as regional and grouped organisation. Developments of those days shows that there was ad hock meetings of almost all these organisations, be it G-8, G-20, OECD or EU; and India and china have been invited as special guest even in those organisation of which they are not member because it had been realised that they have potential to destabilise the US economy and their support is very much required to save the US economy. First visit of US president Barack Obama to china after his just electoral win as president and his gesture in front of china's president and thereafter visit to India indicates to please these countries. This kind of international politics has helped a lot to US economy. Almost all the countries, be it developed or developing, implemented a pro US policy. Even country like India has announced

special packages of billion and billion rupees because of which its fiscal deficit has increased from below 2.69 per cent in 2007-08 to 6.19 per cent in 2008-09. Same kind of expansionary policies were followed by Government of other countries which has helped to save US economy by creating demand for its industrial and service sector.

International politics and world institutions have also played significant role in saving the US currency by maintaining artificial confidence with US \$ as international currency, in-spite of weaken fundamentals of US economy. In this context role of International Monetary Fund (IMF) could have been very critical by promoting SDR as international currency in place of US \$, but it has not taken interest in this concern because in pressure of international politics [13]. Actually IMF and other world institutions are mainly funded by developed countries and among them USA is largest contributor, which generate moral and financial pressure on these institutions not to work against the interest of developed countries in general and USA in particular. USA has also got support from China in this concern, because China is another big beneficiary of exchange rate policy, by artificially maintaining it in lower side. It seems that there is untold understanding between US and China about their exchange rate policy. Whereas USA has artificially maintained its exchange rate in higher side in one side, it is got compensated and supported by China in another side by maintaining its exchange rate in lower side. Both the countries are gaining their own way by this kind of opposite policies because of their different stages of development. Whereas China aim to grow at very fast rate by exporting rest of the world, USA wish to sustain its super economic power status, and this kind of opposite exchange rate policies are in their respective interest.

\section{Conclusion}

Subprime crisis had badly affected to US financial system, which is evident in almost all the fundamental parameters of financial system viz. non-performing assets (NPA), capital to risk-weighted asset ratio (CRAR), and return on assets (ROA). Collapsing of US financial system has also affected to its real economic activities and through it to economic activities of other developed and developing countries. However, available evidence indicates that developed countries were affected more severely than developing countries. It has created a 
Citation: Yadav DK (2015) Recent Financial Crisis and International Politics: An Analysis of Efforts to Save US Economy at the Cost of Developing Economies. J Glob Econ 3: 155. doi:10.4172/2375-4389.1000155

Page 6 of 6

situation like great depression of 1929 , and people were expecting that it may change the global order of economies. It was expected that Asian countries may strengthen their position at the cost of developed countries, particularly of USA. Emergence of Asian countries may have been an opportunity to convert a multi-polar world from unipolar to the present. But developments of post crisis period shows that nothing much have changed and USA re-emerged as super power within a short span of 2 to 3 years. Re-emergence of USA is coincided with double dip recession in countries like India. Analysis of episode with available evidence clearly indicates that world organisation and international politics has played very critical role to save the US economy and current problems of developing economies. World organisations and institutions have propagated for expansionary fiscal policy to all the countries and due to international politics almost all the countries have followed their suggestion, be it in their interest or not. Whereas in one side expansionary fiscal policy was very much beneficial for developed countries particularly for USA, in another side it was dangerous for countries like India those are facing the problem of double dip recession. Analysis of exchange rate of US \$ in terms of SDR shows that in-spite of weak fundamentals of US economy, value of US \$ remain intact and performed consistently. It was found that again world institutions and international politics have played critical role to save the US \$ by maintaining their artificial confidence in it as international currency. On the basis of these available evidences it is being concluded that financial crisis has not brought any significant change on global order of economies and in this context world institutions, organisations, and international politics has played very critical role.

\section{References}

1. Al Shubiri FN (2010) Impact of bank asset and liability management on profitability: Empirical investigation. Journal of Applied Research in Finance 2: 101-109.

2. Bhaumik S, Piesse J (2004) Are foreign banks bad for development even if they are efficient? Evidences from Indian Banking Industry.

3. $\mathrm{FICCl}$ Survey on the status of the Indian Banking Industry. Progress and Agenda Ahead.

4. Gopalakrishnan MM (2010) Globalization and recent trend in banking. Global Journal of Business and Management Research 10: 38-41.

5. Gopalan S, Rajan RS (2009) Financial sector deregulation in emerging Asia: Focus on foreign bank entry. Institute of South Asian Studies, National University of Singapore.

6. Ratna Manikyan K (2014) Indian banking sector: Challenges and opportunities. Journal of Bussiness and Management 16: 52-61.

7. Mohan R (2006) Financial reforms and monetary policy: The Indian experience.

8. Nitusure RR (2003) E-Banking: Challenges and opportunities. Economic and Political Weekly 38: 5377-5381.

9. Reddy YV (2004) Banking sector in global perspective. Inaugural address as Governor of RBI at Banker's Conference, New Delhi.

10. Reserve Bank of India (2011) The report on currency and finance, various years.

11. Singh P (2007) Global competitiveness of Indian Banks: A study of select banking indicators, Issues of concern and opportunities.

12. Uppal RK (2011) Global crisis: Problem and prospectus for Indian Banking Industry. Journal of Economics and Behavioural Studies 2: 171-176.

13. Sarkar R. Vision 2020 for India the financial sector. Planning commission. 